\title{
SYNTHESIS, STRUCTURES AND ANTIMICROBIAL ACTIVITY OF CHLORO- AND FLUORO-SUBSTITUTED THIOCARBOXYHYDRAZONES
}

\author{
ZENG-XIN LIU* \\ School of Chemistry and Chemical Engineering, Linyi University, Linyi Shandong 276005, P. R. China
}

\begin{abstract}
A series of chloro- and fluoro-substituted thiocarboxyhydrazones, 2-(2-chlorobenzylidene)-N-methylhydrazinecarbothioamide (1), 2-(4-fluorobenzylidene)$\mathrm{N}$-methylhydrazinecarbothioamide (2), and 2-(2-chloro-4-fluorobenzylidene)-N-methylhydrazinecarbothioamide (3), were synthesized and characterized by elemental analysis, IR and UV-vis spectra, and single crystal X-ray diffraction. Structures of the three compounds are similar, but with slight modification by chloro- and fluoro-substitute groups. The crystal structures of the compounds are stabilized by hydrogen bonds and $\pi \cdots \pi$ interactions. The antimicrobial activity of the compounds shows that they are effective against some bacteria.
\end{abstract}

Keywords: thiocarboxyhydrazones; antimicrobial activity; crystal structure; hydrogen bonding.

\section{INTRODUCTION}

The widespread excessive use of antibacterial agents lead to development of more resistant bacteria to commonly used antibiotics. This has led to intense research for new types of antibiotics. Hydrazones are a kind of interesting biological active compounds. In recent years, a number of hydrazones have been reported to have various antimicrobial activities..$^{1-6}$ Thiocarboxyhydrazones are a special kind of hydrazone compounds, with the $\mathrm{C}=\mathrm{O}$ groups replaced by $\mathrm{C}=\mathrm{S}$ groups. The slight modification of the structures leads to more potent antimicrobial activities..$^{7-10}$ In addition, such compounds have potential antitumor and cytotoxic properties. ${ }^{11-13}$ Recent research indicated that halido-substituted hydrazones have more potent activities than those without such substitute groups. ${ }^{14,15}$ In order to explore more effective antimicrobial materials, in the present work, a serious of three chloroand fluoro-substituted thiocarboxyhydrazones, 2-(2-chlorobenzylidene)$\mathrm{N}$-methylhydrazinecarbothioamide (1), 2-(4-fluorobenzylidene)-Nmethylhydrazinecarbothioamide (2), and 2-(2-chloro-4-fluorobenzylidene)-Nmethylhydrazinecarbothioamide (3), have been prepared, characterized, and studied on their antimicrobial activities.

\section{EXPERIMENTAL}

General: All chemicals and solvents used during the synthesis were of AR grade and used as received. 2-Chlorobenzaldehyde, 4-fluorobenzaldehyde, 2-chloro-4-fluorobenzaldehyde and 4-methyl-3-thiosemicarbazide with AR grade were purchased from Aldrich. Elemental analyses (CHN) were performed using a Perkin-Elmer 240 elemental analyzer. Infrared spectrum was recorded on a Nicolate Magna IR 750 series II FT-IR spectrophotometer as $\mathrm{KBr}$ pellet. UV-Vis spectra from 200 to $600 \mathrm{~nm}$ were recorded on a PerkinElmer Lambda-25 spectrophotometer. ${ }^{1} \mathrm{H}$ NMR spectra were recorded on 300 MHz Brucker Advance.

Preparation of the compounds: The compounds were prepared according to the same method. Equimolar quantities of 4-methyl-3-thiosemicarbazide were reacted with 2-chlorobenzaldhyde, 4-fluorobenzaldehyde, and 2-chloro4-fluorobenzaldehyde, respectively, in methanol for $3 \mathrm{~h}$, and the reaction progress was monitored by TLC. Then, the solvent was removed by distillation to give colorless solid. The precipitate formed was filtered and washed with methanol and recrystallized from methanol. Single crystals suitable for X-ray diffraction, were obtained by slow evaporation of the methanol solution of the compounds.

2-(2-Chlorobenzylidene)-N-methylhydrazinecarbothioamide (1): Yield, $93 \%$. Anal. Calc. for $\mathrm{C}_{9} \mathrm{H}_{10} \mathrm{ClN}_{3} \mathrm{~S}: \mathrm{C}, 47.5 ; \mathrm{H}, 4.4 ; \mathrm{N}, 18.5 \%$. Found: $\mathrm{C}, 47.3$; $\mathrm{H}, 4.5 ; \mathrm{N}, 18.4 \%$. IR data $\left(\mathrm{KBr}, \mathrm{cm}^{-1}\right): 3296 \mathrm{~m}, 3123 \mathrm{~m}, 2986 \mathrm{w}, 1654 \mathrm{w}, 1543 \mathrm{~s}$, $1523 \mathrm{~s}, 1437 \mathrm{~m}, 1239 \mathrm{~s}, 1158 \mathrm{w}, 1090 \mathrm{~m}, 1034 \mathrm{~m}, 947 \mathrm{w}, 845 \mathrm{~m}, 755 \mathrm{~m}, 657 \mathrm{~m}$, $451 \mathrm{w}$. UV-Vis in methanol $\left[\lambda_{\max }, \mathrm{nm}\left(\varepsilon, \mathrm{L} \mathrm{mol}^{-1} \mathrm{~cm}^{-1}\right)\right]: 320$ (20520), 230 (10360). ${ }^{1} \mathrm{H}$ NMR ( $\left(d^{6}\right.$-DMSO, ppm): $2.99(\mathrm{~s}, 3 \mathrm{H}), 7.40-7.55(\mathrm{~m}, 3 \mathrm{H}), 7.79(\mathrm{~d}$, $1 \mathrm{H}), 9.00(\mathrm{~s}, 1 \mathrm{H}), 11.73(\mathrm{~s}, 1 \mathrm{H})$.

2-(4-Fluorobenzylidene)-N-methylhydrazinecarbothioamide (2): Yield, $87 \%$. Anal. Calc. for $\mathrm{C}_{9} \mathrm{H}_{10} \mathrm{FN}_{3} \mathrm{~S}$ : C, 51.2; H, 4.8; N, 19.9\%. Found: C, 51.1; $\mathrm{H}, 4.8 ; \mathrm{N}, 19.7 \%$. IR data $\left(\mathrm{KBr}^{-1} \mathrm{~cm}^{-1}\right): 3339 \mathrm{w}, 3160 \mathrm{~m}, 2995 \mathrm{w}, 2931 \mathrm{w}, 1609 \mathrm{~m}$ $1555 \mathrm{~s}, 1505 \mathrm{~s}, 1400 \mathrm{~m}, 1233 \mathrm{~s}, 1152 \mathrm{w}, 1085 \mathrm{~m}, 1034 \mathrm{~m}, 929 \mathrm{w}, 830 \mathrm{w}, 582 \mathrm{w}$, $526 \mathrm{w}, 477 \mathrm{w}$. UV-Vis in methanol $\left[\lambda, \mathrm{nm}\left(\varepsilon, \mathrm{L} \mathrm{mol}^{-1} \mathrm{~cm}^{-1}\right)\right]: 315(18315) .{ }^{1} \mathrm{H}$
NMR ( $d^{6}$-DMSO, ppm): $2.99(\mathrm{~s}, 3 \mathrm{H}), 7.33(\mathrm{~d}, 2 \mathrm{H}), 7.80(\mathrm{~d}, 2 \mathrm{H}), 8.59(\mathrm{~s}, 1 \mathrm{H})$, $11.32(\mathrm{~s}, 1 \mathrm{H})$.

2-(2-Chloro-4-fluorobenzylidene)-N-methylhydrazinecarbothioamide (3): Yield, $90 \%$. Anal. Calc. for $\mathrm{C}_{9} \mathrm{H}_{9} \mathrm{ClFN}_{3} \mathrm{~S}$ : C, 44.0; H, 3.7; N, 17.1\%. Found: C, 44.1; H, 3.6; N, 17.3\%. IR data $\left(\mathrm{KBr}^{2} \mathrm{~cm}^{-1}\right): 3296 \mathrm{~m}, 3141 \mathrm{w}, 2986 \mathrm{w}, 2930 \mathrm{w}$, $1598 \mathrm{~m}, 1555 \mathrm{~s}, 1518 \mathrm{~m}, 1481 \mathrm{~m}, 1425 \mathrm{w}, 1394 \mathrm{w}, 1245 \mathrm{~s}, 1090 \mathrm{~m}, 1040 \mathrm{~m}, 910 \mathrm{w}$, $855 \mathrm{~m}, 669 \mathrm{w}, 619 \mathrm{w}, 445 \mathrm{w}$. UV-Vis in methanol $\left[\lambda_{\max }, \mathrm{nm}\left(\varepsilon, \mathrm{L} \mathrm{mol}^{-1} \mathrm{~cm}^{-1}\right)\right]: 318$ (22525), 233 (10220). ${ }^{1} \mathrm{H}$ NMR ( $d^{6}$-DMSO, ppm): 2.99 (s, 3H), 7.19 (s, 1H), $7.26(\mathrm{~d}, 1 \mathrm{H}), 7.78(\mathrm{~d}, 1 \mathrm{H}), 8.93(\mathrm{~s}, 1 \mathrm{H}), 12.05(\mathrm{~s}, 1 \mathrm{H}), 11.55(\mathrm{~s}, 1 \mathrm{H})$.

$X$-ray data collection and structure refinement: Suitable single crystals of the compounds were selected and mounted in air onto thin glass fibers. Accurate unit cell parameters were determined by a least-squares fit of $2 \theta$ values, and intensity data sets were measured on a Bruker Smart 1000 CCD diffractometer with Mo K $\alpha$ radiation $(\lambda=0.71073 \AA)$ at room temperature. The intensities were corrected for Lorentz and polarization effects, but no corrections for extinction were made. The structures of the compounds were solved by direct methods using the SHELXL 97 program. ${ }^{16}$ The non-hydrogen atoms were located in successive difference Fourier syntheses. The final refinement was performed by full matrix least-squares methods with anisotropic thermal parameters for non-hydrogen atoms on $F^{2}$. The amino hydrogen atoms were located from difference Fourier maps and refined isotropically, with $\mathrm{N}-\mathrm{H}$ distances restrained to $0.90(1) \AA$. The remaining hydrogen atoms were located at the calculated positions. Crystallographic data and experimental details for structure analyses are summarized in Table 1. Selected bond lengths and angles of the complexes are listed in Table 2.

Fungal assay: C. albicans (ATCC 10231) was grown on Sabouraud dextrose agar (SDA) plates at $37{ }^{\circ} \mathrm{C}$ and maintained at $4{ }^{\circ} \mathrm{C}$ for short-term storage. Cultures were routinely sub-cultured every $4-6$ weeks. Cultures were grown to the stationary phase (approximately $1 \times 10^{8}$ cells $\mathrm{cm}^{-3}$ ) overnight at $37^{\circ} \mathrm{C}$ in minimal medium $(2 \% \mathrm{w} / \mathrm{v}$ glucose, $0.5 \% \mathrm{w} / \mathrm{v}$ yeast nitrogen base, $0.5 \% \mathrm{w} / \mathrm{v}$ ammonium sulphate), again at $37{ }^{\circ} \mathrm{C}$. The complex (200 $\mathrm{mg}$ ) were dissolved in DMSO $(1.0 \mathrm{~mL})$ and diluted by water $(9.0 \mathrm{~mL})$ to give a stock solution with concentration of $2.0 \times 10^{3} \mu \mathrm{g} \mathrm{mL}^{-1}$. Doubling dilutions of the solution were made to yield a series of test solutions. Minimum inhibitory concentrations $\mathrm{MIC}_{100}$ values (minimum concentration required to inhibit $100 \%$ of cell growth) were then determined using the broth microdilution method.

Bacterial screening: Bacteria were maintained on Nutrient Agar plates at $4{ }^{\circ} \mathrm{C}$ and cultured in liquid broth when required. Liquid broth was used for the antibacterial testing. Liquid broth $(13 \mathrm{~g})$ was dissolved in water $(1000 \mathrm{~mL})$ in a Duran bottle, and then dispensed into $250 \mathrm{~mL}$ conical flasks, autoclaved and allowed to cool. Solutions of the complex were prepared by dissolving the complex $(20 \mathrm{mg})$ in DMSO $(0.5 \mathrm{~mL})$. To the solution was added sterilised Millipore water $(9.5 \mathrm{~mL})$ to produce a stock solution of concentration $2.0 \times 10^{-3}$ $\mu \mathrm{g} \mathrm{mL}{ }^{-1}$. Stock solution $(0.5 \mathrm{~mL})$ was added to sterile water $(9 \mathrm{~mL})$ to produce a drug solution with concentration of $100 \mu \mathrm{g} \mathrm{mL}-1$, and with the concentration of DMSO being $0.5 \%$. This solution $(100 \mu \mathrm{L})$ was added to a microtiter plate. 1:1 serial dilutions were made so as to produce a test concentration range of $50-0.1 \mu \mathrm{g} \mathrm{mL}^{-1}$. Both E. coli and MRSA were grown in liquid broth at $37^{\circ} \mathrm{C}$ and $200 \mathrm{rpm}$ to an $\mathrm{OD}_{600}$ of 1.0. The microtiter plate was inoculated with 100 $\mu \mathrm{L}$ of bacterial cells $\left(\mathrm{OD}_{600}=1.0\right)$. The plates were incubated at $37^{\circ} \mathrm{C}$ for 24 $\mathrm{h}$ and $\mathrm{OD}_{600}$ values were read using an RMX plate reader to give $\mathrm{MIC}_{50}$ values (minimum concentration required to inhibit $50 \%$ of cell growth). 
Table 1. Crystallographic data for the compounds.

\begin{tabular}{|c|c|c|c|}
\hline & 1 & 2 & 3 \\
\hline Empirical formula & $\mathrm{C}_{9} \mathrm{H}_{10} \mathrm{ClN}_{3} \mathrm{~S}$ & $\mathrm{C}_{9} \mathrm{H}_{10} \mathrm{FN}_{3} \mathrm{~S}$ & $\mathrm{C}_{9} \mathrm{H}_{9} \mathrm{ClFN}_{3} \mathrm{~S}$ \\
\hline Formula weight & 227.7 & 211.3 & 245.7 \\
\hline Crystal system & Monoclinic & Monoclinic & Monoclinic \\
\hline Space group & $C 2 / c$ & $P 2 / c$ & $C 2 / c$ \\
\hline \multicolumn{4}{|l|}{ Unit cell dimensions } \\
\hline$a(\AA)$ & $14.3289(8)$ & $7.4960(6)$ & $13.850(2)$ \\
\hline$b(\AA)$ & $8.0603(5)$ & $14.8095(10)$ & $8.9415(11)$ \\
\hline$c(\AA)$ & $18.7173(11)$ & $9.3833(6)$ & $18.167(3)$ \\
\hline$\beta\left({ }^{\circ}\right)$ & $90.892(2)$ & $97.590(2)$ & $92.963(2)$ \\
\hline Cell volume $\left(\AA^{3}\right)$ & $2161.5(2)$ & $1032.5(1)$ & $2246.7(5)$ \\
\hline Number of formula units/cell $(Z)$ & 8 & 4 & 8 \\
\hline$D_{\text {calc }}\left(\mathrm{g} \mathrm{cm}^{-3}\right)$ & 1.399 & 1.359 & 1.453 \\
\hline$F(000)$ & 944 & 440 & 1008 \\
\hline Absorption coefficient $\left(\mathrm{mm}^{-1}\right)$ & 0.510 & 0.291 & 0.509 \\
\hline Temperature $(\mathrm{K})$ & $298(2)$ & $298(2)$ & $298(2)$ \\
\hline Wavelength $(\AA)$ & 0.71073 & 0.71073 & 0.71073 \\
\hline Crystal size $(\mathrm{mm})$ & $0.23 \times 0.21 \times 0.20$ & $0.23 \times 0.23 \times 0.22$ & $0.17 \times 0.15 \times 0.15$ \\
\hline$\theta$ Range for data collection $\left({ }^{\circ}\right)$ & $2.18-26.42$ & $2.59-25.50$ & $2.71-25.50$ \\
\hline Index ranges $(h, k, l)$ & $-17,17 ;-10,10 ;-23,19$ & $-9,9 ;-16,17 ;-11,11$ & $-16,14 ;-10,9 ;-21,20$ \\
\hline Completeness to theta & $26.42(98.7 \%)$ & $25.50(99.6 \%)$ & $25.50(99.7 \%)$ \\
\hline Maximum and minimum transmission & $0.8917,0.9048$ & $0.9360,0.9387$ & $0.9185,0.9276$ \\
\hline Total number of reflections measured & 10522 & 8784 & 9040 \\
\hline Totle number of unique reflections $\left(R_{\text {int }}\right)$ & $2195(0.0269)$ & $1915(0.0368)$ & $2077(0.0305)$ \\
\hline Number of observed reflections $[I>2 \sigma(I)]$ & 1885 & 1519 & 1644 \\
\hline Data/restraints/parameters & $2195 / 2 / 134$ & $1915 / 2 / 134$ & $2077 / 2 / 143$ \\
\hline Goodness-of-fit on $F^{2}$ & 1.053 & 1.050 & 1.037 \\
\hline Final $R$ indices $[I>2 \sigma(I)]$ & $R_{1}=0.0319, w R_{2}=0.0847$ & $R_{1}=0.0414, w R_{2}=0.1021$ & $R_{1}=0.0359, w R_{2}=0.0882$ \\
\hline$R$ indices (all data) & $R_{1}=0.0397, w R_{2}=0.0917$ & $R_{1}=0.0549, w R_{2}=0.1113$ & $R_{1}=0.0513, w R_{2}=0.0969$ \\
\hline Largest diff. peak and hole (e $\left.\AA^{-3}\right)$ & $0.203,-0.176$ & $0.217,-0.182$ & $0.274,-0.226$ \\
\hline
\end{tabular}

Table 2. Selected bond lengths $(\AA)$ and bond angles $\left(^{\circ}\right)$ for the compounds.

\begin{tabular}{|c|c|c|c|}
\hline 1 & & & \\
\hline C7-N1 & $1.275(2)$ & N1-N2 & $1.373(2)$ \\
\hline $\mathrm{C} 8-\mathrm{N} 2$ & $1.351(2)$ & C8-S1 & $1.692(2)$ \\
\hline $\mathrm{C} 8-\mathrm{N} 3$ & $1.319(2)$ & & \\
\hline C7-N1-N2 & 116.1(1) & N1-N2-C8 & 119.3(1) \\
\hline N2-C8-S1 & 119.1(1) & $\mathrm{N} 2-\mathrm{C} 8-\mathrm{N} 3$ & $116.8(1)$ \\
\hline \multicolumn{4}{|l|}{2} \\
\hline C7-N1 & $1.272(2)$ & $\mathrm{N} 1-\mathrm{N} 2$ & $1.369(2)$ \\
\hline $\mathrm{N} 2-\mathrm{C} 8$ & $1.352(3)$ & C8-S1 & $1.682(2)$ \\
\hline C8-N3 & $1.325(2)$ & & \\
\hline C7-N1-N2 & $117.1(2)$ & N1-N2-C8 & $120.2(2)$ \\
\hline N2-C8-S1 & $123.8(2)$ & $\mathrm{N} 2-\mathrm{C} 8-\mathrm{N} 3$ & $117.1(2)$ \\
\hline \multicolumn{4}{|l|}{3} \\
\hline C7-N1 & $1.281(2)$ & N1-N2 & $1.368(2)$ \\
\hline $\mathrm{N} 2-\mathrm{C} 8$ & $1.355(2)$ & $\mathrm{C} 8-\mathrm{S} 1$ & $1.687(2)$ \\
\hline C8-N3 & $1.315(3)$ & & \\
\hline C7-N1-N2 & $115.8(2)$ & N1-N2-C8 & $120.5(2)$ \\
\hline N2-C8-S1 & $119.0(2)$ & $\mathrm{N} 2-\mathrm{C} 8-\mathrm{N} 3$ & $116.2(2)$ \\
\hline
\end{tabular}

\section{RESULTS AND DISCUSSION}

Chemistry: 4-Methyl-3-thiosemicarbazide treated with appropriate aldehydes to produce the desired products (Scheme 1). The purity of all products was determined by TLC using several solvent systems of different polarities. The synthesized compounds were characterized by elemental analysis, IR and UV-vis spectra, and ${ }^{1} \mathrm{H}$ NMR spectra.<smiles>[X]c1ccc(C=O)c([X])c1</smiles>

Scheme 1. Synthesis of the compounds. 1: $\mathrm{X}=\mathrm{Cl}, \mathrm{Y}=\mathrm{H} ; \mathbf{2}: \mathrm{X}=\mathrm{H}, \mathrm{Y}=$ $\mathrm{F} ; 3$ : $\mathrm{X}=\mathrm{Cl}, \mathrm{Y}=\mathrm{F}$.

Spectra analysis: The ${ }^{1} \mathrm{H}$ NMR spectra of the compounds show signals at about 11-12 ppm, which are related to the protons of the NH groups. The signals of the protons on the $\mathrm{CH}=\mathrm{N}$ double bonds appear at about 8.5-9.0 ppm, and the aromatic protons occur in the range 7.2-7.8 ppm. The signals indicative of the protons of the $\mathrm{CH}_{3}$ groups are located at $2.99 \mathrm{ppm}$.

The IR and UV-vis spectra (Fig. 1) of the compounds are very similar. The medium and sharp bands at about $3300 \mathrm{~cm}^{-1}$ are assigned to the $v_{\mathrm{NH}}$. The bands observed at slight over and below $3000 \mathrm{~cm}^{-1}$ are assigned to the aromatic and aliphatic C-H vibrations. The intense bands at about $1550 \mathrm{~cm}^{-1}$ are due to the absorption of the $\mathrm{C}=\mathrm{N}$ bonds. ${ }^{17}$ The medium bands in the region $830-860$ 
$\mathrm{cm}^{-1}$ are attributed to the $v_{\mathrm{C}-\mathrm{s}}$. The absorptions of the electronic spectra may be assigned to the $\mathrm{n} \rightarrow \pi^{*}$ transitions.

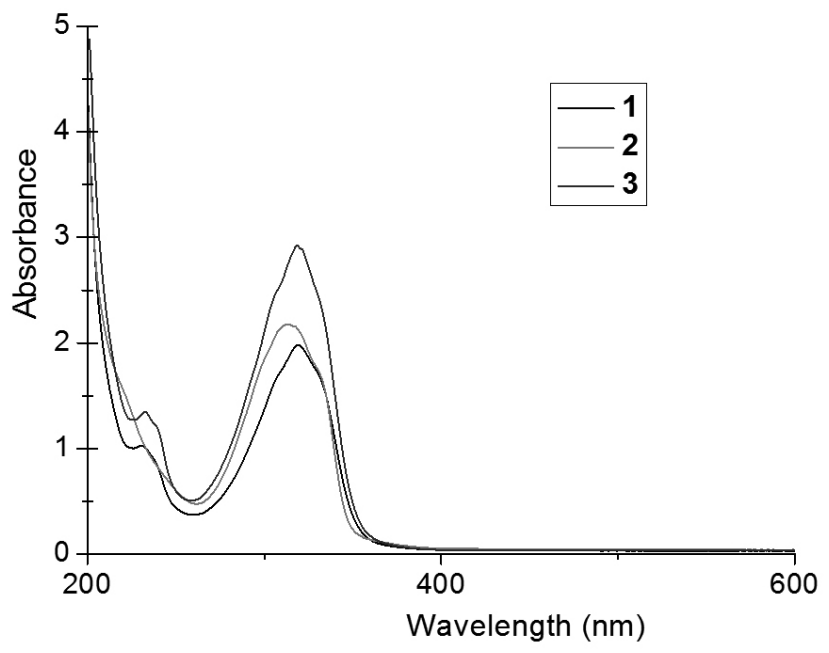

Figure 1. UV-vis spectra of the compounds.

Crystal structure description: The molecular structures of the compounds 1, 2, and 3 are shown in Figures 2, 3, and 4, respectively. In each of the compounds, the sulphur atom and the azomethine nitrogen atom are in trans position with respect to the N2-C8 bond. The molecules of the compounds are not coplanar, as evidenced by the dihedral angles $\left[14.0(4)^{\circ}\right.$ for $1,16.7(3)$ ${ }^{\circ}$ for 2 , and $5.2(3)^{\circ}$ for 3 ] between the $\mathrm{N} 1 \mathrm{~N} 2 \mathrm{C} 8 \mathrm{~S} 1$ thiourea groups and the benzene rings. The bond distances in the thiosemicarbazone side chains agree well with the values observed for similar compounds where the $\mathrm{C}=\mathrm{S}$ groups are present in the thionic form..$^{17}$ There is no obvious charge delocalization in the molecules, as evidenced by the typical $\mathrm{C}-\mathrm{N}$ single bonds between atoms $\mathrm{C} 8$ and $\mathrm{N} 3$.

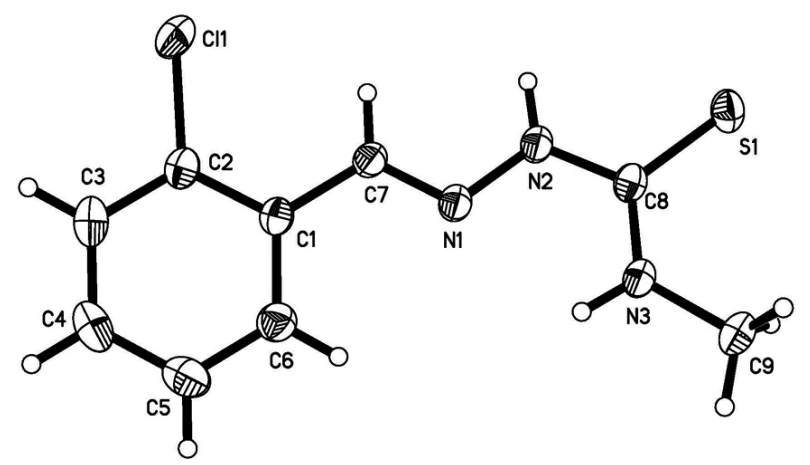

Figure 2. ORTEP view of the molecular structure of $\mathbf{1}$, showing the atom numbering scheme for non-hydrogen atoms.

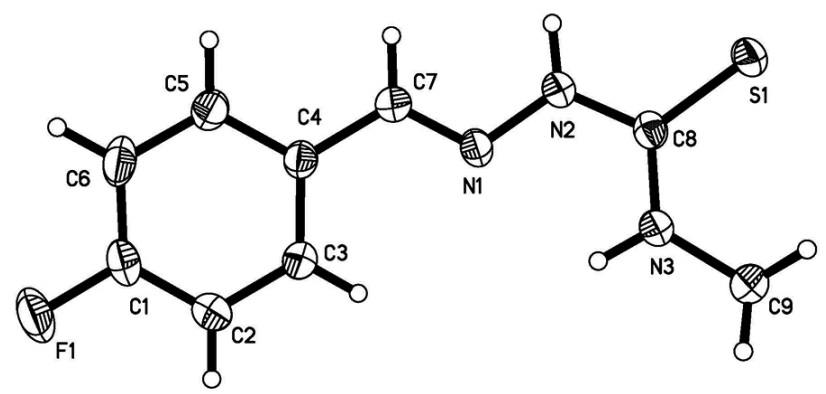

Figure 3. ORTEP view of the molecular structure of $\mathbf{2}$, showing the atom numbering scheme for non-hydrogen atoms.

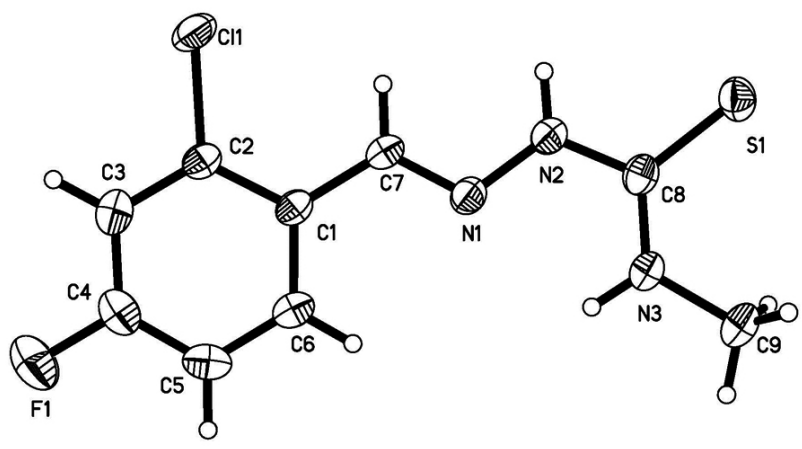

Figure 4. ORTEP view of the molecular structure of $\mathbf{3}$, showing the atom numbering scheme for non-hydrogen atoms.

In the crystal packing diagram of the compounds (Figure 5 for 1, Figure 6 for 2, Figure 7 for 3), molecules are linked through intermolecular $\mathrm{N}-\mathrm{H} \cdots \mathrm{S}$ hydrogen bonds (Table 3 ) and $\pi \cdots \pi$ interactions (Table 4 ), to form $1 \mathrm{D}$ chains.

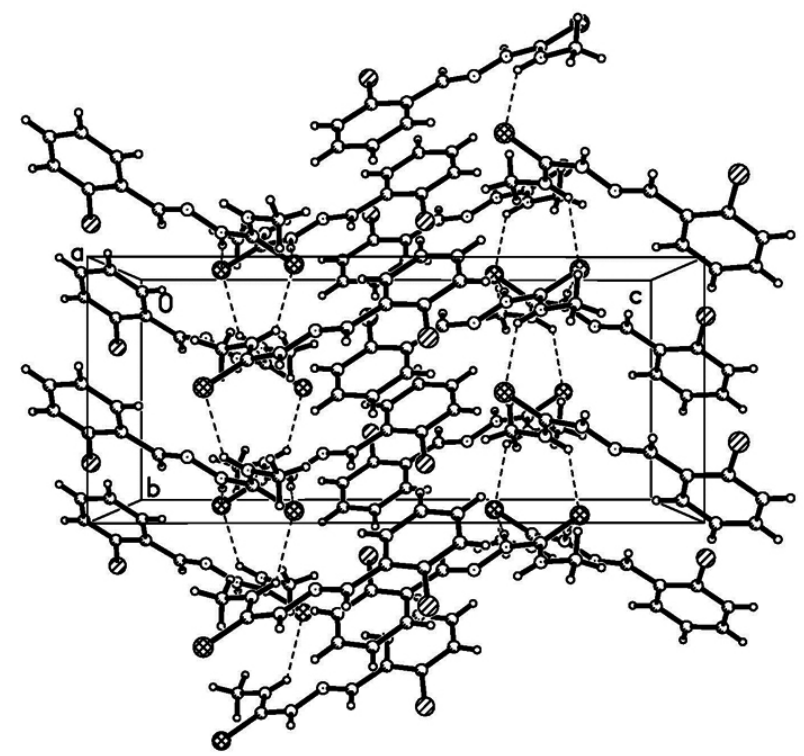

Figure 5. Molecular packing diagram of $\mathbf{1}$. Hydrogen bonds are drawn as dashed lines.

Table 3. Hydrogen-bond geometry $\left(\AA,^{\circ}\right)$ for the compounds.

\begin{tabular}{|c|c|c|c|c|}
\hline$D-\mathrm{H} \cdots A$ & $D-\mathrm{H}$ & $\mathrm{H} \cdots A$ & $D \cdots A$ & $D-\mathrm{H} \cdots A$ \\
\hline $\mathbf{1}$ & & & & \\
\hline $\mathrm{N} 3-\mathrm{H} 3 \mathrm{~A} \cdots \mathrm{S} 1^{\mathrm{i}}$ & $0.90(1)$ & $2.83(2)$ & $3.497(2)$ & $133(2)$ \\
\hline $\mathrm{N} 2-\mathrm{H} 2 \cdots \mathrm{S} 1^{\mathrm{ii}}$ & $0.90(1)$ & $2.526(10)$ & $3.414(1)$ & $171(2)$ \\
\hline $\mathbf{2}$ & & & & \\
\hline $\mathrm{N} 3-\mathrm{H} 3 \cdots \mathrm{S} 1^{\mathrm{iii}}$ & $0.90(1)$ & $2.86(2)$ & $3.499(2)$ & $130(2)$ \\
\hline $\mathbf{3}$ & & & & \\
\hline $\mathrm{N} 2-\mathrm{H} 2 \cdots \mathrm{S} 1^{\mathrm{ii}}$ & $0.90(1)$ & $2.58(1)$ & $3.445(2)$ & $165(2)$ \\
\hline
\end{tabular}

Symmetry codes: (i) $1 / 2-x, 1 / 2+y, 3 / 2-z$; (ii) $1-x, y, 3 / 2-z$; (iii) $x$, $3 / 2-y,-1 / 2+z$. 
Table 4. Parameters between the planes for the compounds.

\begin{tabular}{|c|c|c|c|c|c|c|c|}
\hline$C g$ & $\begin{array}{c}\text { Distance } \\
\text { between ring } \\
\text { centroids }(\AA)\end{array}$ & $\begin{array}{l}\text { Dihedral } \\
\text { angle }\left({ }^{\circ}\right)\end{array}$ & $\begin{array}{c}\text { Perpendicular } \\
\text { distance of } C g(\mathrm{I}) \\
\text { on } C g(\mathrm{~J})(\AA)\end{array}$ & $\begin{array}{l}\text { Beta } \\
\text { angle } \\
\left({ }^{\circ}\right)\end{array}$ & $\begin{array}{l}\text { Gamma } \\
\text { angle }\left({ }^{\circ}\right)\end{array}$ & Slippage & $\begin{array}{l}\text { Perpendicular } \\
\text { distance of } C g(\mathrm{~J}) \\
\text { on } C g(\mathrm{I})(\AA)\end{array}$ \\
\hline \multicolumn{8}{|l|}{1} \\
\hline$C g(1)-C g(1)^{\mathrm{iv}}$ & 4.2739 & 0 & -3.5826 & 33.0 & 33.0 & 2.331 & -3.5826 \\
\hline$C g(1)-C g(1)^{\mathrm{v}}$ & 4.6898 & 0 & 3.4799 & 42.1 & 42.1 & 3.144 & 3.4799 \\
\hline \multicolumn{8}{|l|}{3} \\
\hline$C g(2)-C g(2)^{\mathrm{vi}}$ & 3.7558 & 0 & 3.4979 & 21.4 & 21.4 & 1.368 & 3.4979 \\
\hline$C g(2)-C g(2)^{\mathrm{vii}}$ & 4.8459 & 0 & -3.3297 & 46.6 & 46.6 & 3.521 & -3.3297 \\
\hline
\end{tabular}

Biological assay results: The biological assay results are summarized in Table 5 . Compound $\mathbf{1}$ has medium activity against C. albicans and E. coli, but no activity against MRSA. Compounds $\mathbf{2}$ and $\mathbf{3}$ have similar activities against C. albicans and E. coli. As for the activity on MRSA, compound $\mathbf{3}$ is better than compound 2. From the results, it is not difficult to see that the 4-fluoro containing compound $\mathbf{2}$ has stronger activities than the 2-chloro containing compound $\mathbf{1}$. When the chloro and fluoro groups are combined together to one new compound $\mathbf{3}$, the activities are not improved obviously, except for MRSA.

Table 5. Antimicrobial assay results $\left(\mu \mathrm{mol} \mathrm{L} \mathrm{L}^{-1}\right)$.

\begin{tabular}{|c|c|c|c|}
\hline Compound & $\begin{array}{c}\text { C. albicans } \\
\mathrm{MIC}_{100}\end{array}$ & $\begin{array}{c}\text { MRSA } \\
\mathrm{MIC}_{50}\end{array}$ & $\begin{array}{c}\text { E. coli } \\
\mathrm{MIC}_{50}\end{array}$ \\
\hline $\mathbf{1}$ & 12.5 & $>50$ & 25 \\
\hline $\mathbf{2}$ & 3.12 & 25 & 12.5 \\
\hline $\mathbf{3}$ & 3.12 & 12.5 & 12.5 \\
\hline
\end{tabular}

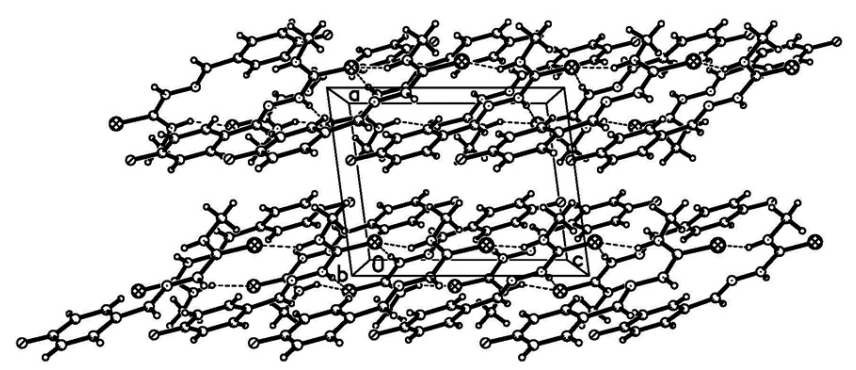

Figure 6. Molecular packing diagram of $\mathbf{2}$. Hydrogen bonds are drawn as dashed lines.

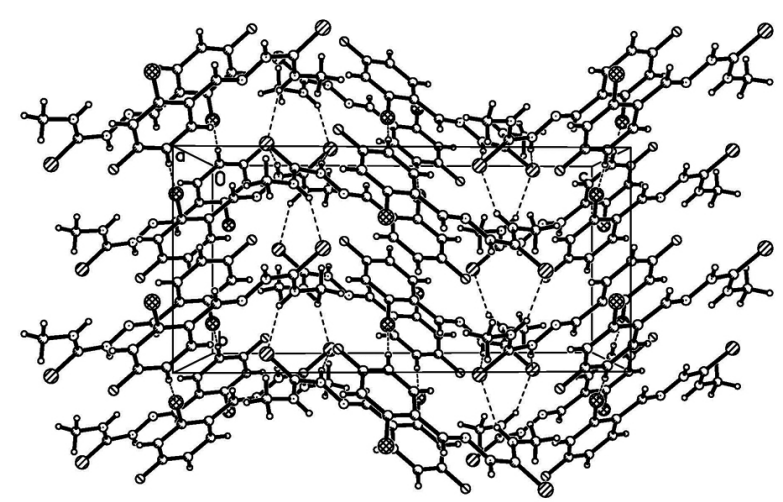

Figure 7. Molecular packing diagram of $\mathbf{3}$. Hydrogen bonds are drawn as dashed lines.

\section{CONCLUSION}

In summary, three new similar chloro- and fluoro-substituted thiocarboxyhydrazones have been prepared and characterized. Single crystal structures of the compounds are presented. The antimicrobial activity of the compounds shows that they are effective against some bacteria.

Supplementary data

Crystallographic data for structural analyses have been deposited with the Cambridge Crystallographic Data Centre, CCDC Nos. 981995 (1), 981996 (2), and 981997 (3). Copies of this information may be obtained free of charge from The Director, CCDC, 12 Union Road, Cambridge, CB2 1EZ, UK (fax: +44 1223336 033; e-mail: deposit@ccdc.cam.ac.uk or http://www.ccdc.cam. ac.uk).

\section{ACKNOWLEDGMENTS}

The author acknowledges the Linyi University for supporting this work.

\section{REFERENCES}

1. M. Alagesan, N.S.P. Bhuvanesh, N. Dharmaraj, Dalton Trans. 42,7210 (2013).

2. M.D. Altintop, A. ozdemir, G. Turan-Zitouni, S. Ilgin, O. Atli, G. Iscan, Z.A. Kaplancikli, Eur. J. Med. Chem. 58, 299 (2012).

3. P. Yang, Y. Wang, Z.-C. Duan, Y. Shao, G.-H. Nie, X.-J. Song, D.-T. Tian, Chin. J. Struct. Chem. 32, 1023 (2013).

4. Z.A. Kaplancikli, M.D. Altintop, A. Ozdemir, G. Turan-Zitouni, S.I. Khan, N. Tabanca, Lett. Drug Des. Discov. 9, 310 (2012).

5. D. Blanot, J. Lee, S.E. Girardin, Chem. Biol. Drug Des. 79, 2 (2012).

6. T. Horiuchi, Y. Takeda, N. Haginoya, M. Miyazaki, M. Nagata, M. Kitagawa, K. Akahane, K. Uoto, Chem. Pharm. Bull. 59, 991 (2011).

7. G.D.K. Kumar, G.E. Chavarria, A.K. Charlton-Sevcik, W.M. Arispe, M.T MacDonough, T.E. Strecker, S.E. Chen, B.G. Siim, D.J. Chaplin, M.L. Trawick, Bioorg. Med. Chem. Lett. 20, 1415 (2010).

8. Y. Li, Z.-Y. Yang, J.-C. Wu, Eur. J. Med. Chem. 45, 5692 (2010).

9. A. Kumar, S. Singh, H. Bordbar, T. Cartledge, S. Ahmed, Lett. Drug Des. Discov. 8, 241 (2011).

10. D.S. Raja, N.S.P. Bhuvanesh, K. Natarajan, Eur. J. Med. Chem. 46, 4584 (2011).

11. K. Hu, Z.-H. Yang, S.-S. Pan, H.-J. Xu, J. Ren, Eur. J. Med. Chem. 45, $3453(2010)$.

12. A.I. Matesanz, P. Souza, Mini-Rev. Med. Chem. 9, 1389 (2009).

13. I. Dilovic, M. Rubcic, V. Vrdoljak, S.K. Pavelic, M. Kralj, I. Piantanida, M. Cindric, Bioorg. Med. Chem. 16, 5189 (2008).

14. C. Congiu, V. Onnis, Bioorg. Med. Chem. 21, 6592 (2013).

15. M. Zhang, D.-M. Xian, H.-H. Li, J.-C. Zhang, Z.-L. You, Aust. J. Chem. 65,343 (2012)

16. G.M. Sheldrick, Acta Crystallogr. A64, 112 (2008).

17. M.B. Ferrari, S. Capacchi, G. Reffo, G. Pelosi, P. Tarasconi, R. Albertini, S. Pinelli, P. Lunghi, J. Inorg. Biochem. 81, 89 (2000). 